\title{
LIMA BARRETO: LITERATURA, MÚSICA E EXISTÊNCIAS
}

\author{
ARAUJO, Erick ${ }^{1}$
}

RESUMO: O artigo oferta uma releitura das palavras de Lima Barreto sobre a chamada música popular. Propõe-se uma análise das críticas destinadas ao autor, aproximando-as das críticas ao jazz. Por fim, vê-se o papel vital, ou mortificante, da música em relação, não apenas a indivíduos, mas a todo um povo.

PALAVRAS-CHAVE: literatura brasileira; música; cultura afro-diaspórica.

\section{LIMA BARRETO: LITERATURE, MUSIC AND EXISTENCES}

\begin{abstract}
We offer a re-reading of the Lima Barreto's words about popular music. We analyze the critics aimed at the author, bringing them closer to the criticisms of jazz. Finally, is brought to light the vital, or mortifying, role of music in relation, not only to individuals, but to an entire people.
\end{abstract}

KEYWORDS: Brazilian literature; music; afro-diasporic culture.

"A Música, a música, essa é nossa história" BARAKA, 2009, p. 29

\section{INTRODUÇÃO}

Um preto velho perambula ao soar seu instrumento e cantar. Uma preta velha é acossada pelo antigo senhor que está atrás de sua sabedoria musical. Um trovador negro inova a modinha, pensa sobre ela, teoriza, e a faz "dizer algo". Que se lembre, também, de Joaquim dos Anjos, pai de Clara, tocador de flauta, tido como primeiro flautista da região onde nasceu, nos arredores de Diamantina, Minas Gerais. Há, ainda, Ricardo Coração dos Outros e o vilão Cassi - que

Estágio Pós-doutoral - Ppghis/Ufop. ericklaraujo@gmail.com 


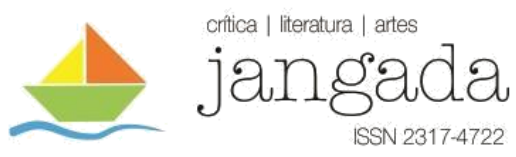

compartilham o violão e a pele branca. A música aparece de diferentes formas nos romances de Lima Barreto. Seja por meio de certas personagens, seja enquanto mera ambientação, ela se faz presente. Em diversas crônicas, ela é assunto do autor. Ainda estudante da Escola Politécnica, Lima publica, em 1900, texto sobre um concerto de Francisco Braga, a respeito do qual diz: "parece-me, nunca será um compositor popular, o que é talvez uma qualidade de primeira ordem" (BARRETO, 2004a, p. 60). Tal enunciado ressoará nas leituras e interpretações acerca da postura de Lima Barreto em relação à chamada música popular, a ponto de se dizer que o autor mantinha certo pensamento elitista e preconceituoso em relação a ela. Trata-se de uma leitura apressada, mas justificável. Talvez os adjetivos deveriam ser outros, mais apurados. Pois o que se mostra nítido em Lima Barreto é o fato de que uma suposta origem, dita popular ou nacional, de qualquer coisa, não lhe diz muito. $\mathrm{O}$ ponto que merece atenção é, a um só tempo, o funcionamento e seus efeitos. É assim com a literatura, será assim com a música. E, nesse sentido, podem ser feitas de Lima Barreto as palavras de outro autor, Mário de Andrade (2013, p. 342): “eu acredito que deveríamos retornar a uma concepção mais ética da arte”. E mais: toda a obra de Lima Barreto - o permanente vai e vem entre ficção e vida, âmbitos que, desse modo, não param de se afetar - é, também, proposição de uma concepção mais artística da ética.

Mas é preciso, antes de prosseguir, fazer dois apontamentos introdutórios. Na verdade, trata-se de repetir dois enunciados, fazendo com que eles sirvam aqui. O primeiro é do próprio Lima Barreto (2004a, p. 131): "Pouco entendo de semelhante arte, mas quero mostrar uma pequena observação que venho fazendo de há muito". Essa é a primeira frase da crônica $A$ música, publicada originalmente em 30 de dezembro de 1914. O segundo é de Mário de Andrade (2013, p. 80), coincidentemente primeira linha de um texto seu: "Uma das coisas mais desagradáveis deste mundo é a gente abrir porta aberta". Dois enunciados que dizem muito sobre o que se tenta fazer aqui, pois trata-se, exatamente, de uma pequena observação sobre uma arte que se entende pouco e, ao fazê-la, corre-se o risco de, somente, abrir portas já abertas. Mas que, mesmo assim, se caminhe.

\section{O DESTINO DA ARTE}

“Anda tudo isso, música, pintura, teatro, verso e prosa, tão ligado na finalidade da arte, que bem se pode encontrar nesse afastamento [entre tais atividades] um dos defeitos de todos esses ramos dela entre nós" (BARRETO, 2017, p. 78). E se sabe qual é a finalidade da Arte para o autor da Vila Quilombo: adicionar inteligência e felicidade à humanidade a partir da compreensão mútua, da multiplicação de conexões entre as pessoas. Para tanto, há um ciclo entre ideias e sentimentos, 
ou melhor, uma relação de chamado-resposta entre ideias e sentimentos. As primeiras, para Lima Barreto, não possuem grande poder de contágio, não são eficientes quando se trata de se fazer compreender para, assim, ligar-se: uma "pura ideia só como ideia tem fraco poder sobre a nossa conduta” (BARRETO, 2017, p. 274). (E, aqui, já se realça o caráter ético da arte: que ela seja, ao mesmo tempo, um discurso de segunda ordem sobre a moral - a conduta - e um motor de transformação da mesma). E a arte é capaz de transformar ideias em sentimentos. Talvez transformação não seja a melhor palavra, pois Lima Barreto diz que é como se os sentimentos transportassem as ideias. Pode-se dizer, seguindo o autor, que as ideias já possuem um quociente sentimental que torna possível a tomada de dianteira dos sentimentos. Trata-se, para modificar uma analogia platônica, de um revezamento entre quem guia a carruagem e quem a puxa. Nesse sentido, o que se chama de estético é a composição de técnicas, de meios e de materiais que permitirão, de modos mais ou menos eficientes, esse revezamento e a concretização de sua finalidade, a saber: "que se soldem as almas" (BARRETO, 2017, p. 275), "quanto mais compreendermos os outros que nos parecem, à primeira vista, mais diferentes, mais intensa será a ligação entre [a humanidade], e mais nos amaremos mutuamente, ganhando com isso a nossa inteligência, não só a coletiva como a individual” (BARRETO, 2017, p. 279). Em suma, a arte "tendo o poder de transmitir sentimentos e ideias, sob a forma de sentimentos, trabalha pela união da espécie; assim trabalhando, concorre, portanto, para o seu acréscimo de inteligência e de felicidade" (BARRETO, 2017, p. 279-80). E que se lembre, a arte não é apenas um fenômeno social, é, também, "sociológico" (BARRETO, 2017, p. 270). Ou seja, além de produto da vida coletiva, ela é meio de compreensão e intervenção na vida social. A arte é, para Lima Barreto, um meio de compreensão do estado de coisas através da exposição dos efeitos de tal estado sobre as mais diferentes vidas. Exposição que se dá por meio do revezamento/compartilhamento de sentimentos e ideias enquanto produtos do asfixiamento das singularidades por tal estado de coisas - que se lembre das palavras de Lima Barreto (1961, p. 43) sobre Isaías Caminha na Breve Notícia: "Deus escreve direito por linhas tortas, dizem. Será mesmo isso ou será de lamentar que a felicidade vulgar tenha afogado, asfixiado um espírito tão singular? Quem sabe lá?”. Não se trata de mera exposição, pois quando metamorfoseados e transportados em e pela arte, tais ideias e sentimentos tem um poder de contágio entre as pessoas. Contágio que gera compreensão, que por sua vez gera solidariedade e amor, sentimentos que tornam intolerável a miséria material a qual grandes parcelas da humanidade são mantidas. Intolerância que se faz sinal de que se caminha em direção oposta daquela da miséria existencial imposta pelo estado de coisas vigente. A arte é meio de transformação, pois é "crítica da vida" e "aspiração a uma vida melhor" (ANDRADE, 2013, p. 344). Não uma 


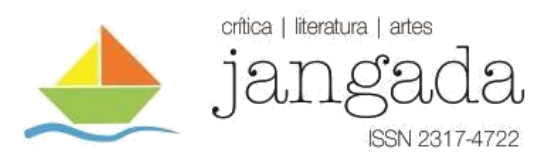

aspiração passiva, mas o primeiro passo na constituição de um novo possível. Pois, a questão é acerca da "própria funcionalidade primeira da arte, no sentido em que a arte é sempre uma crítica da vida, no sentido também em que crítica é consertar...” (ANDRADE, 2013, p.343). Tal compreensão ética, estética, social e política da arte servirá de base para, em seus romances e crônicas, Lima Barreto problematizar a música e seu papel no pós-abolição.

\section{A PROBLEMATIZAÇÃO DA MÚSICA}

Quando se diz problematizar a música, principalmente quando se diz que pouco se entende de tal arte, como afirma Lima Barreto, compreende-se que se lida aí com algo que se poderia resumir como um funcionamento social da música, algo que seria exterior à própria música. No entanto, tal problematização não exclui, na verdade desde já considera, uma análise estética e que tenha em foco, também, suas rupturas criativas. Nesse sentido, problematizar a música é, desde o início, problematizar o estado de coisas. (Pois, como se disse, a música enquanto arte é, desde seu nascimento, problematização do presente). E se sabe que nos romances de Lima, qualquer problematização é traçada por meio das personagens. Elas são o desenvolvimento de um problema. Assim, apenas uma constelação de certos personagens pode permitir que se traga à luz tal problematização e, consequentemente, algo como uma perspectiva barretiana acerca da música, em especial, da dita música popular.

Tal problematização atravessa, principalmente, dois romances: Triste fim de Policarpo Quaresma e Clara dos Anjos; e se desenvolve por meio de quatro personagens músicos. Em Triste fim: Ricardo Coração dos Outros e o trovador negro. Em Clara dos Anjos: Cassi Jones e Joaquim dos Anjos. Todos modinheiros. E o fato de a modinha conectar personagens tão diferentes - incluindo aí um vilão típico, como Cassi, algo raro nos livros do autor - deveria se configurar como um obstáculo para interpretações que tendam a tornar monolítica a perspectiva de Lima Barreto sobre esse estilo. Pois se há Cassi, de um lado; há, de outro, Joaquim. Se há Ricardo, há, também, o músico negro. Tratam-se de quatro variáveis de um problema, que desde o seu início não é simples.

Dentre diferentes versões sobre o nascimento da modinha, uma delas parece se impor: a impossibilidade de lhe dar uma origem exata. Criação portuguesa ou brasileira? Erudita ou popular? (RODRIGUES, 2013). Sabe-se da postura de Lima Barreto em relação as questões de origem: são insolúveis (BARRETO, 2010, p. 68). Portanto, o caminho a ser percorrido é outro. No caso de Triste fim, vê-se, inicialmente, um foco na funcionalidade, pois Policarpo Quaresma se pergunta "qual seria a expressão poético-musical característica da alma nacional" 


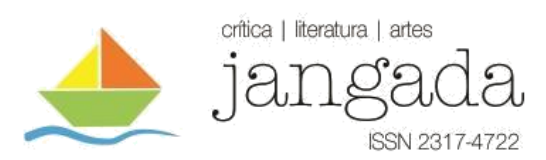

(BARRETO, 1997b, p. 23). E graças a longos momentos de meditação, além de consultas a "historiadores, cronistas e filósofos", Quaresma adquire a certeza que é "a modinha acompanhada pelo violão" (BARRETO, 1997b, p. 23). Não há aí, pelo menos a princípio, uma busca pela origem autenticamente nacional da modinha. Trata-se de uma questão de adequação e eficiência expressiva. Assim, de "acordo com sua paixão dominante", ou seja, a nação, Quaresma decide aprender o violão e a modinha. Ricardo Coração dos Outros, "homem célebre pela sua habilidade em cantar modinhas e tocar violão" (BARRETO, 1997b, p. 22), aparece, então, como seu professor. A caracterização de Ricardo é já de interesse, pois aponta para uma distinção sócioterritorial entre os tocadores de modinha: "Não se julgue, entretanto, que Ricardo fosse um cantor de modinhas aí qualquer, um capadócio. Não; Ricardo Coração dos Outros era um artista a frequentar e a honrar as melhores famílias do Méier, Piedade e Riachuelo"; "gozava de estima geral da alta sociedade suburbana. É uma alta sociedade muito especial e que só é alta nos subúrbios” (BARRETO, 1997b, p. 22). Fala-se, aí, da classe média, mimetizando, sempre de modo retardatário a classe rica, tendo por fim, sobretudo, seu distanciamento, mais imaterial do que material, da classe trabalhadora.

Pode-se dizer que tal cenário no qual a modinha é apresentada está em sintonia com a apresentação feita por Mário de Andrade (2013, p. 19): “nos salões burgueses, desde os fins do século XVIII, se veio formando um gênero nacional de canção amorosa, em que a influência europeia era também fortíssima, a modinha" e em "meados do século passado [séc. XIX] a modinha passou dos salões burgueses pro seio do povo, e aí conseguiu caracterização nacional definitiva". Pois, "nascida em Portugal ou no Brasil, coisa que ainda não se esclareceu definitivamente e duvido que já agora se esclareça, a modinha é legitimamente brasileira": o "que realiza, justifica e define uma criação nacional folclórica é sua adaptação pelo povo" (ANDRADE, 2013, p. 80). Contudo, mesmo tornando-se popular, a modinha "jamais conseguiu [...] aqueles caracteres de formulário construtivo, de tradicionalização, de inconsciência e anonimato da coisa folclórica” (ANDRADE, 2013, p. 320). E há nessa última consideração algo interessante. Em Triste fim, a classe alta suburbana é representada, inclusive em suas festas e bailes, pela casa do general Albernaz. Uma visita de Ricardo e seu violão à casa desperta "no general e na família um gosto pelas festanças, cantigas e hábitos genuinamente nacionais", contudo "a modinha era pouco; os seus espíritos pediam coisa mais plebéia, mais característica e extravagante" (BARRETO, 1997b, p. 28). A passagem parece denotar, de um lado, a ideia da popularização da modinha - o que Mário de Andrade (2013, p. 320) chamará de “desnivelamento", vocabulário afim àquele empregue em Triste fim acerca do "tenaz trabalhar de Ricardo Coração dos Outros em prol do levantamento da modinha e do violão" (BARRETO, 
1997b, p. 80) - e, de outro, o exotismo.

Parece pertinente dizer que o exotismo apresenta os maiores riscos aos coletivos aos quais se imputa o predicado de exóticos, pois funciona pela captura e desvitalização das produções expressivas e artísticas, como também o aprisionamento desses coletivos a certas produções vistas como propriamente suas, ou seja, originais, autênticas. Em poucas palavras, o exotismo é o meio pelo qual o "outro é transformado em puro objeto, espetáculo, marionete..." (BARTHES, 1980. p. 172). Cabe destacar que o nacionalismo, a mania de Policarpo Quaresma - para usar o termo empregado por Adelaide, sua irmã -, está imbricado com o exotismo. Isso se torna visível na relação de Quaresma com os elementos da vida indígena. Como se sabe, o protagonista estuda a língua tupi-guarani tendo como projeto propô-la língua geral, pois seria a autêntica língua nacional. Diz-se que se trata de exotismo pois a autenticidade que Quaresma dá ao tupi-guarani e, daí, sua luta para fazê-lo língua nacional, faz ele perder de vista dois aspectos importantes: a variedade de línguas indígenas (que se recorde que o Tupi-Guarani é uma família linguística, não uma língua, mas que se siga o vocabulário do romance) presentes no Brasil, e os povos aos quais elas pertencem. Quaresma, em sua proposta, expropria um traço expressivo (existencial) - uma língua; torna-o independente de seus falantes (fazendo desses falantes reserva, longínqua, de autenticidade); o faz girar segundo os critérios de seu próprio projeto.

Algo similar se dá no caso da música. Inicialmente, parece ser possível interpretar que Quaresma se mostra interessado na funcionalidade, adequação e eficiência expressiva da música. Desse interesse chega à modinha. Mas logo se vê que sua mania não permite tal perspectiva. E isso deveria ter sido previsto, afinal o protagonista partiu de "sua paixão dominante" e, como se sabe, a paixão "cega", e aquela pela nação o faz "mais do que nenhuma outra", pois "sáfara e estérill" (BARRETO, 2004a, p. 536). O protagonista é levado, desde tal paixão, sua mania, a se desentender, inclusive, com Ricardo.

Direcionando-se a Olga, afilhada de Quaresma, Ricardo ressaltará a beleza e a dificuldade do violão. Seguiria dando um exemplo, mas é interrompido pelo major que afirma existirem instrumentos mais difíceis. Ricardo pergunta se seria o piano. "Qual piano! O maracá, a inúbia”, responde Quaresma, que parece se exaltar ainda mais quando o trovador diz desconhecê-los. "Não conheces? É boa! Instrumentos mais nacionais possíveis, os únicos que o são verdadeiramente; instrumentos dos nossos antepassados", os “caboclos!”. Ricardo deixará visível que compartilha da noção de que os povos indígenas e suas criações não merecem atenção: "Instrumento de caboclo, ora!". A discussão ascende com a resposta do major: "De caboclo! Que é que tem? O Léry diz que são muito sonoros e agradáveis de ouvir... Se é por 


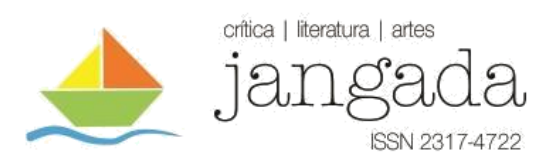

ser de caboclo, o violão também não vale nada - é um instrumento de capadócio". "De capadócio, major! Não diga isso..." (BARRETO, 1997b, p. 37). Há certos pontos dignos de atenção, nesse momento final da discussão. Por um lado, a extensão, feita por Ricardo, do desprestígio destinado aos caboclos - modo genérico de referir-se às populações indígenas considerado, em muitos contextos da atualidade, ofensivo - aos seus instrumentos; e, por outro lado, a aparente desvinculação, feita por Policarpo, entre as pessoas e os elementos produzidos por ou associados a elas. Parece que o major não questiona o desprestígio direcionado aos indígenas, parece mesmo reafirmá-lo quando diz que se a associação entre pessoas e suas criações fosse determinante, o violão, instrumento de Ricardo, também não valeria nada. Nesse sentido, que se recorde de Adelaide, irmã do protagonista, e seu desinteresse pelo violão: "sua educação que se fizera, vendo semelhante instrumento entregue a escravos ou gente parecida, não podia admitir que ele preocupasse a atenção de pessoas de certa ordem" (BARRETO, 1997b, p. 63).

Se Quaresma chega a considerar, inicialmente, o violão como instrumento de interesse patriótico, e depois o maracá e a inúbia, pode-se dizer que se repete com os instrumentos o mesmo procedimento empregado com a língua. Parece pertinente dizer que exotismo é o motor de arranque da instrumentalização de elementos expressivos de certos povos. E quando se diz povos é necessário ter em mente que a tênue delimitação entre eles é produzida, em grande medida, pelo funcionamento de tais elementos enquanto meios de expressar um certo modo de existir singular, ou seja, esses elementos são a via para a constituição, enquanto presença singular no mundo, de um povo. São, assim, elementos vitais. A instrumentalização procede por meio da desvinculação e desvitalização desses elementos em prol de certo objetivo, podese dizer, da maioria. Que se lembre: maioria e minoria não dizem respeito a números, mas sim à aproximação ou distanciamento de um certo modelo (DELEUZE, 2010). Modelo sempre cambiante e redundante, existencialmente vazio, característica que lhe dá força centrífuga, algo que o faz inabitável. Por isso o modelo é ninguém, e as pessoas, se aproximando mais ou menos, se mantêm em sua perseguição. Nesse sentido, a maioria está mais próxima ao modelo, ou seja, mais próxima ao nada. A instrumentalização, assim, aparece como efeito dessa aproximação ao vazio, pois trata-se de uma tentativa de ganhar vida por meio da captura de certos elementos vitais exógenos. No entanto, não há ganho de vida para a dita maioria. O que ocorre é a desvitalização desses elementos quando extirpados de seus contextos existenciais, tornando-os novas ferramentas de esvaziamento. E é nessa direção que, talvez, seja menos útil pensar na ligação óbvia que há entre os dois modinheiros Ricardo e Cassi Jones, do que naquela entre Cassi e Policarpo Quaresma. Há uma variação no objetivo - a glória da nação para Policarpo, 


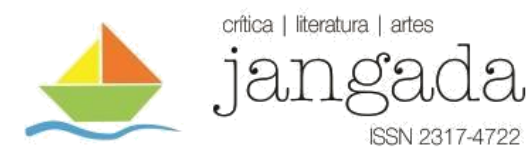

a sedução de mulheres para Cassi - mas um procedimento comum - a instrumentalização. E no caso de Cassi, pode-se dizer, isso é quase literal: "Era bem misterioso esse violão; era bem um elixir ou talismã de amor” (BARRETO, 1997a, p. 33); “e, quase sempre, o violão e a modinha eram seus cúmplices..." (BARRETO, 1997a, p. 48).

Deve-se ter atenção, pois caso a análise se restrinja a Cassi - a seus trejeitos enquanto toca e canta, às letras amorosas das modinhas e, principalmente, a seu objetivo - pode-se chegar, de modo apressado, à conclusão de que tal personagem representaria o desprezo de Lima Barreto pela música popular. Entretanto, cabe lembrar de Joaquim dos Anjos, pai de Clara, apresentado como honesto e trabalhador: o "carteiro [...] não era homem de serestas e serenatas; mas gostava de violão e de modinhas. Ele mesmo tocava flauta, instrumento que já foi muito estimado em outras épocas, não sendo atualmente como outrora" (BARRETO, 1997a, p. 21). Portanto, não se trata apenas da modinha. Há certo agenciamento, cujo funcionamento conjunto de seus elementos dá efetividade às ações de Cassi sobre Clara. Ou seja, não se lida apenas com o efeito das modinhas - que "falam muito de amor, algumas delas são lúbricas até" (BARRETO 1997a, p. 72) - sobre a protagonista. Soma-se à modinha os efeitos das "reações mentais" da jovem "ao áspero proceder da mãe", proceder que lhe limitava o acesso ao mundo, não a preparando para encará-lo; e a superficial relação com o pai, constituída enquanto uma preparação para a vida de casada - "o seu ideal na vida não era adquirir uma personalidade, não era se ela, mesmo ao lado do pai ou do futuro marido. Era constituir função do pai, enquanto solteira, e do marido, quando casada" (BARRETO, 1997a, p. 166). Que não se esqueça do racismo enquanto parte constituinte de tal agenciamento que, a um só tempo, permitia a Cassi escolher mulheres negras como seu alvo preferencial, dado: 1) seu cálculo de maior probabilidade de sucesso de suas investidas devido ao fato de ser branco. Fato que denotaria uma pureza de sentimentos, pois um possível casamento entre um homem branco e uma mulher negra implicaria o enfrentamento da hierarquia racial vigente; 2) sua certeza da impossibilidade de defesa por parte das mulheres perante as consequências negativas de suas ações sobre elas, devido ao apoio institucional que tende à branquitude, apoio visível quando o caráter explícito do papel de perpetrador é ofuscado pelo salvo-conduto dado a priori àqueles que compartilham à condição de brancos. Algo que Lima Barreto faz ver quando se coloca, lado a lado, Ismênia, de Triste fim, e Clara: os modos pelos quais o sexismo tem efeitos distintos em relação a mulheres brancas e negras, devido ao funcionamento associado do racismo. Mostra, com Ismênia, que as mulheres brancas são formadas enquanto objetos frágeis e valiosos para o casamento. O termo utilizado em Triste fim é bibelot. As mulheres negras, como é o caso de Clara, são vistas, por um lado, enquanto meros objetos a serem usados e, por outro, enquanto 


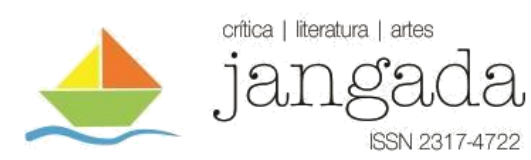

sedutoras maléficas. Ou seja, não há fragilidade nem valorização, há apenas uso e culpabilização. O uso é explícito na personagem de Cassi, já a culpabilização, na de sua mãe, que o defende cegamente, devido a um orgulho étnico - de classe e necessariamente associado a um orgulho racial. Em suma, a associação e a retroalimentação desses elementos fazem de Clara um alvo de Cassi, atualizam a coisificação a qual a população negra era submetida, agora investida sobre a jovem na pós-abolição: "ela deixou de ser ela mesma, para ser uma coisa, uma boneca nas mãos dele" (BARRETO, 1997a, p. 154). O que a leva, ao final do livro, a concluir, em conversa com sua mãe: "Nós não somos nada nessa vida." (BARRETO, 1997a, p. 172). Mas há um aprendizado no sofrimento. Devido aos acontecimentos, ela passa a ver, nítida e diretamente, o estado de coisas: "Agora é que tinha a noção exata da sua situação na sociedade" (BARRETO, 1997a, p. 171). E mais do que apontar para um triste fim de Clara dos Anjos, algo anunciado tanto no receio de Clara em ser expulsa de casa por estar grávida quanto no encontro de Cassi com "sua primeira vítima" (BARRETO, 1997a, p. 149) - ela encontrava-se na miséria e seu filho com o modinheiro, preso - o que se vê é diverso: um abraço em sua mãe, que a acolhe, e o estreitamento da aliança com Dona Margarida, a vizinha nascida na Rússia. Clara sofre, mas aprende como funciona o Brasil, e o fato de o livro apontar para a manutenção de suas alianças, inclusive a familiar, abre caminho para a interpretação de que tal aprendizado pode gerar frutos benéficos.

Que se recorde que a música, especificamente a modinha, no caso de Clara, é elemento, pode-se dizer, alienante. Pois fomenta sua incompreensão do mundo, inclusive o desconhecimento do lugar geralmente destinado a uma jovem negra. O que Lima Barreto deixa explícito é a necessidade de conhecer esse lugar para empregar forças para dele sair, se desviar, e, idealmente, para destruí-lo. Clara o conhece sofrendo. E a modinha é elemento atuante nesse sofrimento. Entretanto, há ainda um detalhe. Diz-se que a modinha atua no caso de Clara, mas não se pode dizer que seria assim em qualquer situação. Algo a ser considerado, pois nítido no livro, é o fato de Clara ser audiência. Seu pai, apesar de lhe ensinar "os rudimentos da arte musical” (BARRETO, 1997a, p. 116), não lhe ensinou nenhum instrumento. Apenas o piano seria apropriado "para uma moça" (BARRETO, 1997a, p. 116). Como seu pai não podia comprar, alugar, nem mesmo pagar aulas de piano, Clara fica, portanto, restrita à audiência. Por que se diz isso? Pois enquanto meio de expressão existencial - modo de constituição de um estilo expressivo próprio ao tocar um instrumento - a música, inclusive a modinha, poderia funcionar de modo diverso, sendo útil a Clara. Mas, como se disse, no agenciamento em questão, a música acaba atuando tanto no fomento e manutenção da ignorância acerca do estado de coisas quanto como meio de diferenciação e hierarquização étnica - o que inclui o ethos de classe - 


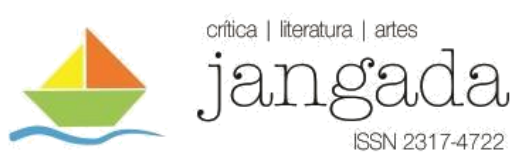

fazendo de certos estilos musicais e instrumentos signos, sempre cambiantes, de pertencimento. Daí se poder dizer "que já em 1856" havia "a detestável moda de tocar piano", o que tornava possível "chamar o Rio de Janeiro de "cidade de pianos"”; "a praga era tão geral no país" que era possível "encontrar pianos a cem léguas, interior a dentro, transportados a ombro de negro" (ANDRADE, 2015, p. 125). Pode-se dizer que não há apenas peso material, mas também imaterial. E nesse sentido, uma longa passagem de Triste fim parece importante, pois mostra que Ricardo:

sofria na sua glória, produto de um lento e seguido trabalho de anos. É que aparecera um crioulo a cantar modinhas e cujo nome começava a tomar força e já era citado ao lado do seu. Aborrecia-se com o rival, por dois fatos: primeiro: pelo sujeito ser preto; e segundo: por causa das suas teorias. Não é que ele tivesse ojeriza particular aos pretos. O que ele via no fato de haver um preto famoso tocar violão era que tal coisa ia diminuir ainda mais o prestígio do instrumento. Se o seu rival tocasse piano e por isso ficasse célebre, não havia mal algum; ao contrário: o talento do rapaz levantava a sua pessoa, por intermédio do instrumento considerado; mas, tocando violão, era o inverso: o preconceito que lhe cercava a pessoa desmoralizava o misterioso violão que ele tanto estimava. E além disso com aquelas teorias! Ora! Querer que a modinha diga alguma coisa e tenha versos certos! Que tolice! E Ricardo levava a pensar nesse rival inesperado que se punha assim diante dele com um obstáculo imprevisto na subida maravilhosa para a sua glória. Precisava afastá-lo, esmagá-lo, mostrar a sua superioridade indiscutível; mas como? A réclame já não bastava; o rival a empregava também. Se ele tivesse um homem notável, um grande literato, que escrevesse um artigo sobre ele e a sua obra, a vitória estava certa. Era difícil encontrar. Esses nossos literatos eram tão tolos e viviam tão absorvidos em coisas francesas... Pensou num jornal, O Violão, em que ele desafiasse o rival e o esmagasse numa polêmica. Era isso que precisava obter e a esperança estava em Quaresma, atualmente recolhido ao hospício, mas felizmente em via de cura. A sua alegria foi justamente grande quando soube que o amigo estava melhor (BARRETO, 1997b, p. 63-64).

Está tudo aí. Mas que não se condene Ricardo apressadamente. Que se tenha calma na análise. Lima Barreto faz ver, em Triste fim, que a mania é um trabalho, é "coisa feita", que acaba por constituir seres. É o caso de Policarpo Quaresma, Ismênia e Ricardo. A mania do último é a glória. Sim, no seu caso, parece não haver herança, portanto há trabalho para conquistá-la. Mas há algo mais. Há o favor: que um grande literato, talvez Quaresma, escreva 


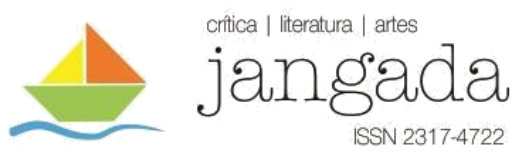

sobre ele, exaltando-o. E que se lembre de Isaías Caminha que, graças a seu tio, conseguiu uma carta de recomendação de um coronel de sua cidade natal. Mas logo se viu, em seu caso - um jovem negro interiorano -, a inutilidade da carta. O que denota que a funcionalidade do favor se relaciona com certo pertencimento prévio a um grupo. $\mathrm{O}$ aborrecimento de Ricardo com o novo tocador de modinhas e a solução por ele aventada - um artigo de um prestigioso literato - para superá-lo, parece corroborar com a afirmação acerca do favor como elemento de um ethos. Mas não só o favor. O fato da ascensão do modinheiro negro incomodar Ricardo parece dizer que a glória é, também ela, elemento restrito a certo grupo, um grupo que seria, a priori, superior. Afinal, o que se mostra aí é que não se trata do resultado de um trabalho melhor ou mais abundante. O novo modinheiro toca, canta, e além disso, pensa sobre o que toca e canta; busca criar, modificar a música. Mas Ricardo considera-o rival. Precisa, portanto, esmagá-lo, mostrar "sua superioridade indiscutível". Mas que superioridade seria essa? Não seria uma superioridade musical. Ela se daria e seria afirmada, exatamente, por meio das palavras de um grande literato de seu ciclo de relações. Ciclo que, como Lima Barreto mostra, não é outra coisa senão um ciclo étnico. Talvez seja relevante, nesse sentido, ressaltar o fato de Ricardo morar em uma casa de cômodos no subúrbio, ou seja, lugar pobre. Mesmo aí, na pobreza, é possível traçar uma linha que faz com que Ricardo se distingua do novo modinheiro e se conecte a indivíduos de outra classe social, conexão que não só corrobora a distinção, como lhe dá valoração, estabelecendo uma hierarquia entre os dois modinheiros, cujo ponto de maior valor seria ocupado pelo amigo de Quaresma. Traça-se de um grupo que desconsidera as divisões de classe (para mantê-las), e reafirma a divisão e a hierarquia racial. A divisão de classes só se sustenta se os brancos pobres tiverem assegurada a divisão e a hierarquia racial.

Mas que se vá com calma. Para Ricardo a música não deve dizer diretamente nada. $\mathrm{Ou}$ seja, as palavras devem aparecer, apenas, como elementos sonoros a serem adaptados a melodia. Por um lado, Ricardo expressa que a música não precisa de palavras para ser meio de expressão existencial. Ele mesmo sofre quando não pode tocar seu violão no quartel. Ou seja, a música, para Ricardo, não é apenas meio para a glória. É algo vital. Traço comum entre ele e Joaquim dos Anjos - esse não busca a glória na música, tampouco procura inová-la, como o faz o modinheiro negro, mas afirma que vive para ela. Por outro lado, Ricardo não vê que as palavras reproduzidas nas canções dizem, sim, algo. Elas redundam uma forma de vida e uma norma expressiva - também redundantes entre si. A modinha não deve dizer nada, a não ser o que já diz. O que se vê é que a potência a-significante da música é sufocada pelas palavras que reafirmam o vazio existencial de certo modelo de vida. Ao dizer potência a-significante procura-se destacar o fato da música, mesmo involuntariamente, emergir como produção 


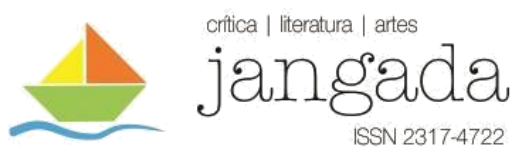

existencial inseparável da possibilidade de abertura a/de algo diferente do estado de coisas, algo como uma existência em estado nascente (LIMA, 2019). Potência a-significante da música quer dizer, ainda, algo como uma capacidade de afetar e ganhar um sentido ao ser tocada e ouvida. O que Lima Barreto parece mostrar é, portanto, que uma suposta origem popular ou uma popularização - enquanto espraiamento de certo elemento entre um povo - não são grandes coisas se aquilo que é dito popular não serve de meio expressivo e não trata das existências. É nesse sentido que o autor critica a música hegemônica de seu tempo ao dizer que é um "atavio, um adorno mundano e vai perdendo aos poucos o que possa haver nela de profundo e importante para o nosso destino" (BARRETO, 2004a, p. 131). Por isso a modinha é um verdadeiro canto das sereias em relação a Clara. E o fato da protagonista se restringir a audiência tem importância pois, ao tocar um instrumento, ela poderia ganhar um novo vocabulário expressivo. Por um lado, haveria a possibilidade de traduzir seus sentimentos em ritmo e melodia. Por outro, seria possível emergir, mesmo a revelia de si mesma, um novo horizonte sentimental. Aspectos que poderiam acarretar o surgimento, o desenvolvimento e a transformação de ideias (pois, em Lima Barreto, como se sabe, sentimentos e ideias vão juntos). Restrita ao papel de audiência de uma música que ecoa uma forma de vida que se impõe como norma vazia, Clara desenvolve uma "alma amolecida" (BARRETO, 1997a, p. 72), "uma natureza amorfa, pastosa” (BARRETO, 1997a, p. 117), isolada.

\section{A MÚSICA PROBLEMATIZANTE}

Mesmo como audiência, entretanto, as coisas poderiam ser diferentes. É o que o blues, o samba, o jazz e o rap, por exemplo, ensinam. Trata-se de criações que emergem de uma encruzilhada de heranças rítmicas e estruturais - como o chamado-resposta (LOPES, 2006; DAVIS, 1999; JONES, 1967) - e de uma capacidade criativa que beira ao infinito, pois é capaz de utilizar, e assim transformar, elementos próprios a um ambiente estranho e hostil. Criações localizadas “em um continuum cultural africano" (DAVIS, 1999, p. 49). E que se ressalte: não é exagero falar em herança nem em continuum, pois a forma do canto antifonal africano estruturado em um solista que apresenta um tema e em um coro que o responde atravessa estilos, territórios e tempos afro-diaspóricos diversos. Há algo como um vínculo entre persistência $e$ complexificação explícito no blues de Gertrude "Ma" Rainey quando ela insere uma antecipação da resposta do coro. Cabe lembrar, também, dessa persistência $e$ complexificação no jazz: "a estrutura riff-solo [tema e improvisação] era adaptação perfeita da antiga música vocal antifonal africana, bem como da canção de trabalho e do spiritual, ambos igualmente 


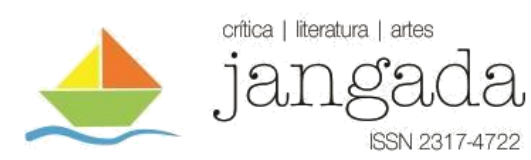

afro-americanos" (JONES, 1967, p. 187). Não foi sem razão que se falou em atravessamento de estilos, territórios e tempos afro-diaspóricos diversos. Pois o canto antifonal dá forma aos vissungos - músicas de trabalho entoadas, principalmente, nas lavras de Diamantina, no estado de Minas Gerais, região natal de Joaquim dos Anjos - que se dividem "em boiado, que é o solo, tirado pelo mestre sem acompanhamento nenhum, e o dobrado, que é a resposta dos outros em coro, às vezes com acompanhamento de ruídos feitos com os próprios instrumentos usados na tarefa" (MACHADO FILHO 1964, p. 57). Vive, também, no samba de partido-alto da cidade do Rio de Janeiro: a "estrofe improvisada a solo e acompanhada de refrão coral fixo, ocorrente no partido-alto ${ }^{2}$, constitui característica estrutural da música de origem africana na Diáspora" (LOPES, 2011, p. 1185). Dessa confluência que parece vir a força arrebatadora dos vissungos cantados por Clementina de Jesus, Tia Doca e Geraldo Filme, no álbum O Canto dos escravos. Daí se poder dizer que "a forma chamado e resposta (solo e coro) da África, nunca nos deixou como um modo (musical) de expressão" (JONES, 2010, p. 195).

Há algo como um efeito dessa forma e de seu atravessar estilístico, territorial e temporal: o fortalecimento $e$ a constituição de comunidades na diáspora. Fortalecimento e constituição que passam, também, pela audiência. É o que "Ma" Rainey faz ao abrir uma canção com o verso "eu quero que todas vocês mulheres me escutem", e segue aconselhando que não se confie demasiadamente "no seu homem". Trata-se aí de um dialogo traçado não apenas com uma audiência, mas com uma "comunidade de mulheres" (DAVIS, 1999, p. 57). Ou seja, lida-se aí com a persistência e complexificação da "forma chamado-resposta", por meio de uma "antecipação das afirmações da audiência" (DAVIS, 1999, p. 55), fazendo do blues - e que se ressalte a importância daquele produzido por mulheres negras: "Quem melhor cantou o blues clássico foram as mulheres” (JONES 1967, p. 99) - um espaço no qual os aspectos profundamente sociopolíticos da experiência pessoal negra tornam-se explícitos, o que possibilita a análise, o dialogo e a troca de experiências individuais-coletivas.

É nesse sentido (dentre outros) que a escrita barretiana - criticada por ser demasiadamente pessoal - se aproxima das músicas negras. Ou melhor, é nesse sentido que a escrita barretiana mostra-se musical. A escrita é o ponto individual que se encontra no meio, ou seja, ela está entre a experiência existencial e a antecipação de uma resposta, ambas coletivas. Mesmo formalmente, romances como Recordações, Triste fim e Clara dos Anjos, configuramse, com as personagens protagonistas, como respostas a problemas existenciais coletivos. No

\footnotetext{
${ }^{2}$ Como explica Candeia, no documentário Partido Alto, de Hirszman (1982), tal modalidade "tem aquela forma da improvisação, a improvisação que vai nascendo não só sobre o tema, refrão, mas também sobre o ambiente, sobre um clima que vai se criando aos poucos".
} 


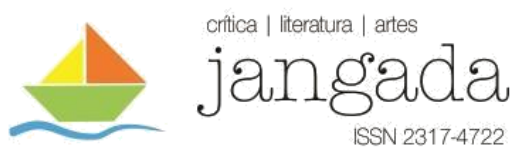

entanto, se há, ao final dos livros, o fechamento de um ciclo responsivo, há uma abertura, um chamado: a insatisfação - que funciona como impulso para movimento de Isaías - cessa precariamente, apenas para, nas últimas páginas, os desgostos (novo impulso?) relativos à sua nova vida emergirem; fecha-se o ciclo de desilusões de Quaresma, mas abre-se o caminho para Olga; Clara é seduzida por Cassi, mas não se aponta para o final provável mostrado no livro por meio das outras vítimas do modinheiro, há uma aliança e um abraço entre mãe e fillha, abraço que aponta, graças ao aprendizado enunciado por Clara ("nós não somos nada nessa vida"), para um caminho diferente daquele já demarcado para o povo negro. Trata-se de criar possíveis na e pela literatura.

Chamado-(antecipação)-resposta, tal é a estrutura musical da obra barretiana. E nesse sentido, se é possível dizer que a música e a literatura são meios de individuação, pois são a expressão pela qual alguém, algum $u m$, um indivíduo ou um povo, se apresenta, se posiciona perante o todo; pode-se afirmar, também, que elas são, desde já, uma abertura ao fora, são meios de desindividuação, são a explicitação da ocupação ou do atravessamento desse um pelo todo. Trata-se de um vai e vem entre o individual, o coletivo, o popular, o planetário e o cósmico, sendo que as passagens de um ao outro não se dão por mera soma ou subtração de elementos, mas por algo como chamados e respostas incessantes entre eles. E há algo mais. Amiri Baraka lembra, em diversas oportunidades, de um ditado africano: “o espírito não descerá sem música". Pode-se dizer, fazendo uso de certa generalização, que as religiões africanas, as afro-brasileiras e pode-se incluir as indígenas, compreendem a relevância musical - pois rítmica e sonora - do mundo material e imaterial, por isso que o necessário intercâmbio entre mundos é dado por meio de uma "afinação", de uma "sintonia". Os tambores africanos e as maracás indígenas ${ }^{3}$ são meios de interlocução, ao mesmo tempo que são meios expressivos, pois manifestam uma atitude, um modo de existir sempre em relação com um fora, com outras forças, com outros mundos. Relação em seu sentido forte, pois o início de sua tessitura depende já de uma abertura aos seus efeitos, às transformações forjadas pelo estar em relação. Por isso dizer: individuação e desindividuação.

Vê-se, assim, a complexidade de se falar que algo é popular, pois ao se falar povo não se quer dizer um conglomerado de pessoas circunscritas pela pátria ou pela nação. Longe disso. Mas falar povo também não é se referir, apenas, a um coletivo étnico. Há algo mais. Aqui, uma pequena frase de Lima Barreto (1956, p. 52), em uma entrada de seu diário, mostra-se

\footnotetext{
${ }^{3}$ É o que mostra Wewito Ashaninka (BESSA FREIRE 2017) ao dizer que a "música nos faz voar. Entramos no som de nossos instrumentos e, através deles, nos relacionamos com pássaros, peixes, ervas, legumes, bebidas e outros seres".
} 


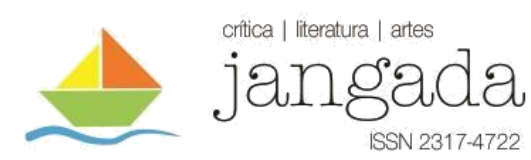

importante: “eu, mulato ou negro, como queiram”. Parece necessário desdobrá-la. Quando se fala de povo negro, fala-se das pessoas negras no Brasil, esse agrupamento constituído por meio da brutalidade do sequestro, do cativeiro, da hierarquia racial e da constituição e manutenção de uma situação de miséria material em uma terra estranha: "mulato ou negro, como queiram". Ao dizer povo negro, povo mulato, povo preto, pouco importa as possíveis diferenças entre os termos que variam: "mulato ou negro, como queiram"; o que se mostra importante é o sentido de uma assunção enquanto resposta e desafio - mesmo com todo a brutalidade e a miséria imposta, emergimos enquanto povo. Que se tenha atenção: tal emersão não é a chegada final à tábua salvadora. Povo é um traço diferencial, é ao mesmo tempo abertura $e$ fechamento; é a habitação de uma passagem, que ao ser transpassada se fecha $e$ se abre em ângulos diversos. Pode-se ainda afirmar que ao enunciar um povo aponta-se para uma constelação provisória. Constelação que torna algo incomensurável, como um universo, inteligível. Mais diretamente: um povo é um traçado pela humanidade e pelo todo. Fala-se povo para poder se falar, também, em humanidade e no mistério que a cerca. Fala-se povo para que se impeça a mania de fazer da humanidade sinonímia de um agrupamento qualquer, essa mania de fazer "esse clube da humanidade" (KRENAK, 2019, p. 13). Para que se bloqueie o ímpeto de forjar, por meio de um agrupamento, um topo da humanidade, como se essa fosse, em vez de um universo de relações, um mero relevo. Ao se falar povo não se faz outra coisa senão evidenciar a humanidade como esse universo de relações que não se restringe àquilo que é dito propriamente humano. $\mathrm{E}$ Lima Barreto sabe disso, pois a tarefa da literatura e da música, seu destino, é, pare ele, tanto um meio de conexão entre a humanidade quanto entre essa e "à árvore, à flor, ao cão, ao rio, ao mar e à estrela inacessível” (BARRETO, 2017, p. 280). A humanidade é um estar entre e ao chegar aos seus limites o que se vislumbra são dois polos do que não se conhece, e talvez, apenas talvez, se possa conhecer; tal é o "Mistério que nos cerca" (BARRETO, 2017, p. 272). Por isso dizer que se lida com uma complexa rede de chamado-(antecipação)-resposta que ao mesmo tempo individualiza e desindividualiza, atravessando o indivíduo, o coletivo, o popular, o planetário e o cósmico. A literatura e a música individualizam, pois são atos expressivos de autoposicionamento, são a apresentação de certa existência enquanto singular. Algo como uma resposta individual a um chamado universal. A literatura e a música desindividualizam, pois pelo próprio ato de autoposicionamento configura-se toda uma vizinhança, rede de compartilhamento de elementos, repetições, ecos, reverberações e atravessamentos. Há algo como uma expressão do universo através (mesmo apesar) do indivíduo: chamado(antecipação)-resposta. Talvez aí se possa compreender quando se fala que o indivíduo (e se pode falar também do povo) "se encontra em posição de 'terminal", pois "a interioridade se 


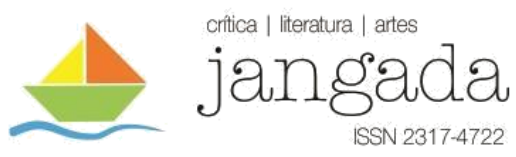

instaura no cruzamento de múltiplos componentes relativamente autônomos uns em relação aos outros e, se for o caso, francamente discordantes" (GUATTARI, 2012, p. 17).

Dito isso, pode-se retornar às palavras de Lima Barreto, elas podem ganhar outra intensidade agora: a música torna-se um "atavio, um adorno mundano e vai perdendo aos poucos o que possa haver nela de profundo e importante para o nosso destino" (BARRETO, 2004a, p. 131). Não é à toa que a música funciona como meio de sedução nas mãos de Cassi; não é gratuito também falar em canto das sereias, pois trata-se de algo como um encantar para que se instaure um bloqueio e para que se finque um desvio nos chamados-respostas - esse incessante movimento musical da existência - erigindo uma câmara na qual os mesmos chamados e as mesmas respostas são dadas insistentemente. Que se recorde de Ricardo: a música perde sua função existencial no momento que funciona como meio para a glória pessoal; e como caminho para a glória, a música deve se fazer redundante com uma norma de vida dada. Fecha-se a câmara e a música se torna redundância, reafirmação e sedução.

\section{RELENDO, COM AUXÍLIO DA MÚSICA, AS CRÍTICAS A LIMA BARRETO}

Pode-se chegar, agora, a outro ponto de contato entre a obra de Lima Barreto e a música negra. Talvez se possa dizer que ambas lidaram com a "incompreensão" por parte da crítica branca. Tal "incompreensão" torna-se explícita nas comparações entre o Recordações e o Triste fim objetivando o enaltecimento do último, pois "Lima Barreto nele conseguiu criar uma personagem que não fosse mera projeção de amarguras pessoais como o amanuense Isaías Caminha" (BOSI, 1974, p. 359). Tem-se a ideia de que Triste fim "revelaria um autor mais maduro e mais voltado para problemas mais gerais" (BEZERRA, 2010, p. 107). Por vezes, a comparação extrapola à obra do autor e passa a ser empregada em relação a ele e Machado de Assis (BUARQUE DE HOLANDA, 1997) com o intuito de denotar a superioridade do último: seus tormentos, semelhantes àqueles de Lima, teriam sido dissimulados de forma efetiva, por isso Machado "triunfa na realização literária" (BUARQUE DE HOLANDA, 1997, p. 11). Parece ser desnecessário apontar para os possíveis tormentos compartilhados entre Lima Barreto e Machado de Assis. Mas é necessário apontar para a suposta necessidade de dissimulação para alcançar o triunfo em literatura: que se apague a experiência negra, para assim produzir arte legítima - ou uma que pessoas brancas possam compreender. Encaixam-se, no mesmo caso, certos elogios aos talentos negros em literatura, tendo como adendo a sugestão de certa ampliação no escopo temático - que se pare de falar de racismo.

Ainda nessa mesma direção, nota-se uma tentativa de cindir o próprio Recordações: "há 


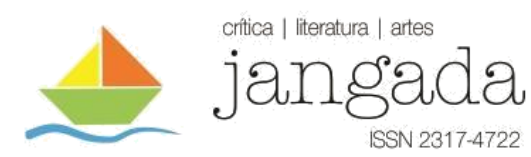

uma nota autobiográfica ilhada e exasperada nos primeiros capítulos; mas tende a diluir-se à medida que o romance progride, objetivando-se e abraçando descrições de tipos vários: o político, o jornalista, o burocrata carioca do começo do século" (BOSI, 1974, p. 358). Afirmase, também, que a concepção militante de literatura de Lima Barreto, cuja missão seria "libertar o homem e melhorar sua convivência" (CANDIDO, 1989, p. 39), impedira-o de "transformar o sentimento e a ideia em algo propriamente criativo" (CANDIDO, 1989, p. 40). Assim, elogiase o Policarpo Quaresma, pois nele se apresentaria um ficcionista a ser admirado, enfatizando que seus "outros romances (mesmo quando o impacto é forte)" ficaram "perto demais do testemunho, do comentário, do desabafo, da conversa sardônica ou sentimental" (CANDIDO, 1989, p. 41). A literatura passa a ser algo como um artefato forjado apenas pelo imaginário, não havendo espaço, então, para a experiência. Caso essa emerja no escrito dito literário é encarada como “um corpo estranho" (BUARQUE DE HOLANDA, 1997, p. 9) a ser expurgado.

Por que se diz incompreensão? E por que se diz que há coincidência entre as críticas acerca da obra de Lima Barreto e aquelas relativas à música negra? Incompreensão porque não se responde à pergunta "por que?", "por que escrever assim?", "por que tocar dessa maneira?". Não se responde, pois nem mesmo se faz tal questão. Os critérios de avaliação já estão estética, política e moralmente determinados. Daí a crítica poder dizer que Recordações é um romance à clef, mesmo autobiográfico - quando, de fato, não é (ARAUJO, 2019) - e, a partir de tal caracterização, poder desprezá-lo e, ao mesmo tempo, poder elevar outras obras à clef de autores brancos. O problema não seria, então, o gênero literário (SCHWARCZ, 2017). O procedimento é similar em relação ao jazz: por um lado, "um saxofone alto como Paul Desmond, homem branco, produz em seu instrumento um som que pode ser quase chamado legítimo, ou clássico" e, por outro, “o melhor dos alto-saxofonistas negros, Charlie Parker, produziu um som no mesmo instrumento ao qual alguns chamaram de 'rouco e inculto'. Mas o som produzido por Parker visava a ser aquilo que ambos os adjetivos descrevem!", pois Parker "imitava literalmente a voz humana com seus gritos, arrebatamentos, grasnidos e borrões sonoros, enquanto Desmond insiste sempre em que está tocando um instrumento que constitui um artefato separado dele". Parker não admitia, sobretudo, a "separação entre si próprio e o agente que escolhera como meio de auto-expressão" (JONES, 1967, p. 39). Os metais, no jazz, carregam a herança da expressividade da voz do blues: o "som cru e bruto que o homem preto extraia desses instrumentos europeus era um som que ele cultivara neste país (EUA) por duzentos anos" (JONES, 1967, p. 87). Por isso não é à toa que, ao tratar da música afrodiaspórica, se fala que ela é, também, história.

Acerca das críticas, pode-se dizer, talvez eufemisticamente, que há uma dificuldade de 


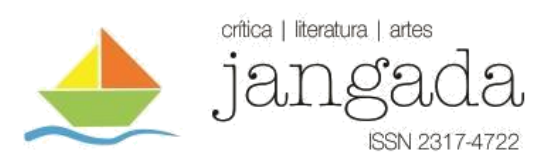

compreensão em relação a obras exteriores a certo grupo circunscrito estética, política e moralmente. E poder-se-ia dizer acerca das palavras de Lima Barreto o que se diz sobre as notas de um solo de jazz: elas existem por razões que são concomitantemente musicais (JONES, 2010, p. 21). E serão compreendidas apenas assim, concomitantemente. Tomando as palavras de LeRoi Jones (posteriormente, Amiri Baraka): a música negra, a literatura negra são atitudes, tomadas de posição, que ocorrem mesmo antes de se escrever e tocar. São modos singulares de olhar e intervir sobre o mundo: dos cantos e gritos de trabalho ao saxofone de Parker; das palavras do griot, para os subúrbios cariocas e, por fim, para as letras impressas de Lima Barreto.

\section{RELENDO A CRÍTICA DE LIMA BARRETO À MÚSICA}

Ora, daí dizer que tanto a escrita quanto a música são criações artísticas que abrem brechas no estado de coisas. Por isso o apreço de Lima Barreto e sua atenção voltada à música, pois ela seria "a única arte em que raramente aparece uma tentativa de criação" (BARRETO, 2004a, p. 307). A perda dessa potência é o que faz o autor da Vila Quilombo dizer que "a arte musical, na nossa cidade, não dá nenhuma demonstração superior da nossa emoção, dos anseios e sonhos peculiares a nós. Limita-se a repetir, trilhando caminhos batidos. Não há invento nem novidade" (BARRETO, 2004a, p. 307). E aí há algo a ser acrescentado. Pois preza-se pela criação e, também, pelo uso que se faz da música. A análise desse ponto afasta conclusões apressadas quanto ao desprezo de Lima Barreto pelas músicas e outras expressões ditas populares. A questão não é, apenas, de locus, mas de uso, funcionamento e efeitos. Suas considerações acerca do carnaval são ilustrativas, já que apontam sua funcionalidade - "o ruído, o barulho, o tantã espancam a tristeza que há nas nossas almas, atordoam-nos e nos enchem de prazer"; “a zabumba é que nos tira do espírito as graves preocupações da nossa árdua vida" (BARRETO, 2004a, p. 137) - como também criticam seu caminhar rumo ao empobrecimento e homogenização - seja “aqui, em Niterói, em Belo Horizonte, em Cuiabá, etc.”, “o que se canta e o que se faz são o supra-sumo da mais profunda miséria mental", o "carnaval é hoje a festa mais estúpida do Brasil" (BARRETO, 2004b, p. 489), "tão igual por toda a parte, que foi impossível, segundo tudo faz crer, ao subúrbio dar-lhe alguma coisa de original" (BARRETO, 2004b, p. 504). Que o tantã e a zabumba espantem a tristeza, mas que o façam abalando os alicerces do presente. Que as músicas e outras performances carnavalescas ampliem a "alegria de viver", mas que sejam também protestos "contra o formalismo, a convenção e as atitudes graves" (BARRETO, 2004a, p. 137).

Além de todas as nuances presentes nos escritos de Lima Barreto acerca da música, 


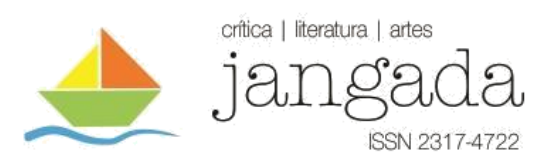

principalmente aquela dita popular, há algo mais. Que se relembre de Maria Rita, em Triste fim. Que não se esqueça do preto velho no porto, em Recordações. Lida-se, aí, com personagens que indicam algo importante: uma ligação vital - e, consequentemente, também mortificante com a música enquanto herança, meio de criação e, também, de instrumentalização. Não é por acaso que o preto velho canta e toca seu instrumento improvisado perambulando por um porto no Rio de Janeiro, enquanto Isaías e outros integrantes do jornal esperam a chegada de um português. Também não é ignorável o fato de, no trajeto para a casa de Maria Rita, lembrada por seu conhecimento e habilidade musical, Quaresma e Albernaz passarem pelos arredores da Fazenda Santa Cruz, latifúndio que até o século XVIII encontrava-se sob domínio dos jesuítas, onde contavam-se milhares de pessoas escravizados para garantir a exploração econômica da área para a Ordem. A fazenda se configurava, também, como "uma espécie de conservatório de música" destinado a "formar negros" (BALBI, 1822, p. CCXIII). Configuração que perdurou com a expulsão dos jesuítas e passagem de seus bens à Coroa, modificando-se, apenas, de algo aos modos de um conservatório para uma escola mais modesta cujo objetivo era de ensinar a artinha para aqueles que seriam os músicos de banda (TINHORÃO, 1972). Nesse sentido, se não foi despropositadamente que se falou em herança e criação, também não o foi quando se falou em instrumentalização. A música não parou de ser utilizada enquanto instrumento de formação: de cristãos $e$ de mão de obra, explorada nos campos, nas casas e nas bandas musicais. Mas não só isso. O que Lima Barreto mostra em Triste fim e em Clara dos Anjos é algo como um agenciamento formativo, um processo incessante e repetitivo que constitui indivíduos, algo ilustrado pelas personagens de Ismênia e de Clara.

Não se fala em constituição sem motivos, pois há uma verdadeira passagem de uma segunda natureza à primeira. No caso de Ismênia isso é explícito: desde criança escuta a mãe dizer que é necessário aprender algo para estar preparada para a vida matrimonial e ao crescer não para de ouvir a pergunta: "afinal, quando se casa?”. Assim, “a menina foi se convencendo de que toda a existência só tendia para o casamento" (BARRETO, 1997b, p. 38). Se ouvir e responder questões acerca do matrimônio é um hábito, se se preparar para a vida de casada é um costume; pode-se dizer que se trata de uma segunda natureza. Quando o casamento não ocorre e Ismênia adoece e morre, vê-se que tal agenciamento formativo faz com que essa segunda natureza passe à primeira. E a música é, na casa de sua família, elemento nesse agenciamento. A música emerge como mais um ato que compõem as festas da casa do general Albernaz, pai de Ismênia. Atos que cumprem a função de "chamar atenção sobre sua casa, atrair gente e... casar as filhas” (BARRETO, 1997b, p. 31). A música é algo como um elemento de ambientação que garante a reprodução de apenas uma forma de vida. Nesse processo, a música 


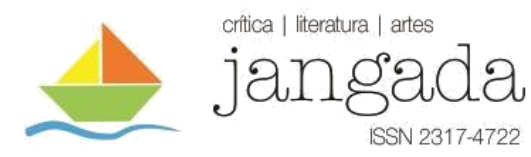

acaba por se desvitalizar, tornando-se redundante com tal forma de vida. Que se lembre que Albernaz vai à casa de Maria Rita, uma ex-escravizada, para tentar extrair dela canções para animarem uma de suas festas. E que não se esqueça, Maria Rita, após falar que não lembra de nenhuma canção, faz questão de lembrar a Albernaz que tratam-se de canções do tempo do cativeiro e pergunta-o sobre o motivo de ele as querer: "É para uma festa... Qual é a que você sabe?” (BARRETO, 1997b, p. 30), ele a responde. Não importa o que essas músicas carreguem. Mesmo que, concomitantemente, sustentem as marcas da desumanização do cativeiro e da potência vital que garante uma brecha de vida num ambiente de morte; sua extração significa o sepultamento de sua história, pois tais músicas passam a girar ao redor de um modelo de vida, passam reafirmá-lo incessante e, daí, sua "nova" difusão funciona como uma sedução, um canto de sereia (é esse canto que seduz a alma amolecida, a natureza pastosa de Clara).

Há algo mais. Já se disse, aqui, que tal modelo é vazio. E isso que mostram os personagens de Lima Barreto mais próximos desse modelo: vê-se um fundo de insatisfação, desalento e exasperação. Algo como um desespero basilar sobre o qual tal modelo se sustenta. Os títulos e as honrarias, os ritos e as festas, as profissões e as funções, as hierarquias e as distinções, elementos cambiantes, a serem perseguidos, para garantir uma maior proximidade ao nada modelar. Dessa maneira, se a música, mas não só ela, desempenha a função de aproximar, manter a proximidade e seduzir em direção a um modelo, sub-repticiamente essa busca pela extração da música e de outros elementos que se mostram, em outros lugares, vitais, é signo de um desespero generalizado. Trata-se, aí, de tentar se agarrar a um fragmento de vida, por menor que ele seja. É o que se vê da reação da família de Albernaz ao ouvir Ricardo tocar e cantar. "Houve em todos um desejo de sentir, de sonhar, de poetar à maneira popular dos velhos tempos" (BARRETO, 1997b, p. 28). Desejo que impulsiona o general e o faz acossar Maria Rita. E o fato da "preta velha" (BARRETO, 1997b, p. 28) resistir e não dar ao general o que ele procura, mesmo sendo ele seu antigo senhor, é sinal de algo. $\mathrm{O}$ fato de se apontar para um aprendizado de Clara, aprendizado que só pode ocorrer com a superação de sua "alma amolecida", também é sinal de algo.

O que se vê é que a formação, a constituição enquanto seres para servir, nunca é completa - o que não quer dizer que ela é pouco danosa. Não é completa pois ela não impede o enriquecimento de um universo referencial que torna possível que, mesmo em condições redutoras e hostis, se possa criar e se possa viver. Por meio de brechas, em becos, faziam-se e fazem-se - mundos se abrirem. Música popular é a que fortalece, até mesmo cria, um povo. Nesse sentido, sabe-se "que a música foi o derivativo principal que os africanos tiveram no exílio da América" (ANDRADE, 2015, p. 139), pois em toda a América escravista, foram os 


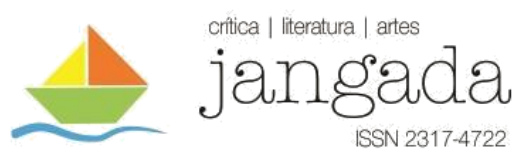

aspectos mais abstratos dos modos de vida africanos que puderam florescer (JONES, 2009). Por isso falar em herança e em ruptura. Há persistência $e$ complexificação, continuidade e criação. Daí não se poder dizer que certos elementos de modos de expressão africanos (e indígenas) sobrevivem na chamada música brasileira. Não há sobrevivência. Há, sim, florescimento. Há uma força vital que, por um lado, provêm a renovação desses diversos modos de existência e, por outro, entre as entranhas da música como instrumento de sedução, passa a reger o que se conhece como música popular no Brasil. Nesse sentido que o impulso para tentar se agarrar a um fragmento de vida, mesmo minúsculo, pode se configurar como uma verdadeira linha de fuga. A formação também não é completa junto a quem está mais próximo do modelo vazio.

Mas que se lembre: tal trabalho de formação - sempre incompleto - perdura. A homogenização e o empobrecimento do carnaval, por exemplo, assim como a responsabilidade da imprensa nisso, aspectos já apontados por Lima Barreto (2004b), são pontos a serem tratados (AZEVEDO, 2018) por aquelas pessoas que têm no samba e no Carnaval meios expressivos vitais (SIMAS, 2020). O mesmo pode ser dito sobre o rap, sobre o jazz, sobre o funk e muitos outros estilos musicais, muitos outros meios expressivos, como a literatura: it's bigger than the hip hop, já o disse dead prez (2000). Isso é maior que a música, maior que a literatura. É maior, pois há, necessariamente, uma ambivalência com a qual se deve lidar: a arte enquanto meio de vitalização $e$ de desvitalização. O ponto é, exatamente, ver a arte com a óptica da vida (NIETZSCHE, 2007). Produzí-la e avaliá-la com o critério da vida. Foi o que Lima Barreto não parou de fazer.

\section{REFERÊNCIAS BIBLIOGRÁFICAS}

ANDRADE, Mário de. Música, doce música. Rio de Janeiro: Nova Fronteira, 2013.

. Pequena história da música. Rio de Janeiro: Nova Fronteira, 2015.

ARAUJO, Erick. Recordações do escrivão Isaías Caminha: a literatura fíccional de testemunho de Lima Barreto. In: Remate de Males, v. 39, n. 1, p. 403-422, 2019. Disponível em: https://periodicos.sbu.unicamp.br/ojs/index.php/remate/article/view/8652207. Acesso em: 03 fev 2021.

AZEVEDO, Amailton Magno. Samba: um ritmo negro de resistência. In: Revista do Instituto de Estudos Brasileiros, n. 70, p. 44-58, 2018. Disponível em: https://www.periodicos.usp.br/rieb/article/view/149632/146687. Acesso em: 22 ago. 2019.

BALBI, Adrien. Essai statistique sur le royaume de Portugal et d'Algarve, comparé aux autres États de l'Europe, et suivi d'iun coup d'oeil sur l'état actuel des sciences, des lettres et des beauxarts parmi les portugais des deux hémisphères. Tome second. Paris: Rey et Gravier, 1822. 


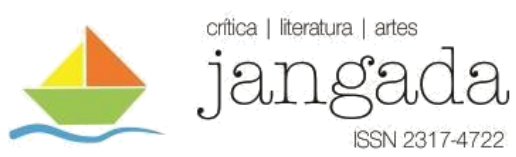

BARAKA, Amiri. Digging: the afro-american soul of american classical music. Berkeley; Los Angeles: University of California Press, 2009.

BARRETO, Lima. Clara dos Anjos. Rio de Janeiro: Ediouro; São Paulo: Publifolha, 1997a.

. Crônicas. In: Resende, Beatriz; Valença, Rachel. Toda Crônica: Lima Barreto. Volume I 1890-1919. Rio de Janeiro: Agir, 2004a.

. Crônicas. In: Resende, Beatriz; Valença, Rachel. Toda Crônica: Lima Barreto. Volume II 1919-1922. Rio de Janeiro: Agir, 2004b.

. Diário do Hospício e Cemitério dos Vivos. São Paulo: Cosac Naify, 2010.

. Diário Íntimo. São Paulo: Brasiliense. 1956.

. Impressões de leitura e outros textos críticos. In: Resende, Beatriz (org.). São Paulo:

Peguin, Companhia das Letras, 2017.

. Triste fim de Policarpo Quaresma. São Paulo: Klick; O Globo, $1997 \mathrm{~b}$.

BARTHES, Roland. Mitologias. São Paulo; Rio de Janeiro: DIFEL, 1980.

BESSA FREIRE, José Ribamar. A flauta do prefeito índio. In: Correio do Brasil. Direto da redação. Rio de Janeiro, 16 jan. 2017. Disponível em: https://bit.ly/3b2ePKU. Acesso em 04 mai. 2020.

BEZERRA, Jane Mary Cunha. Lima Barreto: anarquismo, antipatriotismo e forma literária. 2010. Dissertação, Programa de pós-graduação em Letras, Universidade Federal do Ceará, Fortaleza.

BOSI, Alfredo. História concisa da literatura brasileira. São Paulo: Cultrix, 1974.

BUARQUE DE HOLANDA, Sérgio. Prefácio. In: Barreto, Lima. Clara dos Anjos. Rio de Janeiro: Ediouro; São Paulo: Publifolha, 1997, pp. 8-19.

CANDIDO, Antonio. Os olhos, a barca e o espelho. In: Candido, Antonio. A educação pela noite e outros escritos. São Paulo: Ática, 1989. pp.39-50.

DAVIS, Angela. Blues Legacies and Black Feminism. Gertrude 'Ma' Rainey, Bessie Smith, and Billie Holiday. New York: Vintage Books, 1999.

Dead prez. Let's get free. New York: Loud Records, 2000.

DELEUZE, Gilles. Sobre o teatro. Tradução de Fátima Saadi, Ovídio de Abreu, Roberto Machado. Rio de Janeiro: Jorge Zahar, 2010.

GUATTARI, Félix. As três ecologias. Tradução de Maria Cristina F. Bittencourt. Campinas: Papirus, 2012.

JONES, LeRoi. O Jazz e sua influência na cultura americana. Tradução de Affonso Blacheyre. Rio de Janeiro: Record, 1967.

JONES, LeRoi. Black Music: essays by LeRoi Jones (Amiri Baraka). New York: Akashic, 2010. JONES, LeRoi. Home: social essays by LeRoi Jones (Amiri Baraka). New York: Akashic, 2009. HIRSZMAN, Leon (Dir.). Partido Alto. Embrafilme, 1982. Disponível em: https://web.archive.org/web/20090524012625/http://portacurtas.com.br/Filme.asp?Cod=4751. Acesso em: 22 ago. 2019.

KRENAK, Ailton. Ideias para adiar o fim do mundo. São Paulo: Companhia das Letras, 2019. LIMA, Vladimir Moreira. A partir de Guattari 1: uma política da existência. Rio de Janeiro: Ponteio, 2019.

LOPES, Nei. A presença africana na música popular brasileira. Artcultura, v. 6, n. 9, 2006. Disponível em: http://www.seer.ufu.br/index.php/artcultura/article/view/1370. Acesso em: 21 ago. 2019. 
LOPES, Nei. Enciclopédia brasileira da diáspora africana. São Paulo: Selo Negro, 2011.

MACHADO FILHO, Aires da Mata. O negro e o garimpo em Minas Gerias. Rio de Janeiro: Civilização Brasileira, 1964.

NIETZSCHE, Friedrich. O nascimento da tragédia ou helenismo e pessimismo. Tradução de J. Guinsburg. São Paulo: Companhia das Letras, 2007.

RODRIGUES, Isadora Almeida. Literatura, história e senso comum: Lima Barreto e suas representações do músico popular. 2013. Dissertação. Programa de Pós-graduação em Estudos Literários, Universidade Federal de Minas Gerais, Belo Horizonte.

SIMAS, Luiz Antonio. O desabafo sincopado da cidade: a Estação Primeira de Mangueira como uma instituição política. Concinnitas. v. 21, n. 33, 2020.

TINHORÃO, José Ramos. Música popular de índios, negros e mestiços. Petrópolis: Vozes, 1972. 